Abstracta Iranica Abstracta Iranica

Revue bibliographique pour le domaine irano-aryen

Volume 32-33 | 2013

Comptes rendus des publications de 2009-2010

\title{
Anthony Cutler. Image Making in Byzantium, Sasanian Persia and the Early Muslim World. Images and Cultures
}

\section{Christelle Jullien}

\section{(2) OpenEdition}

12 Journals

Édition électronique

URL : http://journals.openedition.org/abstractairanica/40483

DOI : 10.4000/abstractairanica.40483

ISSN : 1961-960X

\section{Éditeur :}

CNRS (UMR 7528 Mondes iraniens et indiens), Éditions de l'IFRI

\section{Édition imprimée}

Date de publication : 1 décembre 2013

ISSN : 0240-8910

\section{Référence électronique}

Christelle Jullien, « Anthony Cutler. Image Making in Byzantium, Sasanian Persia and the Early Muslim World. Images and Cultures », Abstracta Iranica [En ligne], Volume 32-33 | 2013, document 149, mis en ligne le 01 juillet 2016, consulté le 26 septembre 2020. URL : http://journals.openedition.org/ abstractairanica/40483 ; DOI : https://doi.org/10.4000/abstractairanica.40483

Ce document a été généré automatiquement le 26 septembre 2020.

Tous droits réservés 


\section{Anthony Cutler. Image Making in Byzantium, Sasanian Persia and the Early Muslim World. Images and Cultures}

Christelle Jullien

\section{RÉFÉRENCE}

Anthony Cutler. Image Making in Byzantium, Sasanian Persia and the Early Muslim World. Images and Cultures. Oxon, Ashgate, 2009, 322 p. (Variorum Collected Studies Series CS905).

1 Un seul article de ce troisième volume réunissant les travaux d'Anthony Cutler a trait aux échanges commerciaux entre la Perse sassanide et l'empire romain. Signalons une réflexion sur les influences et les appropriations d'imageries, à travers les productions manufacturées, à Byzance et dans la Bagdad abbasside.

\section{AUTEURS}

CHRISTELLE JULLIEN

CNRS/Mondes iranien et indien, Paris 